\title{
Appraisal of spatial-temporal variation and pollution source estimation of Ganga River system through pollution indices and environmetrics in Upper Ganga basin
}

\author{
Gagan Matta ${ }^{1}$ (D) $\cdot$ Avinash Kumar ${ }^{1} \cdot$ Anjali Nayak ${ }^{1} \cdot$ Pawan Kumar $^{1}$
}

Received: 8 July 2021 / Accepted: 29 November 2021 / Published online: 7 February 2022

(c) The Author(s) 2022

\begin{abstract}
National river of India, Ganga River, nurturing ecological, economic, and socio-cultural aspects defining the last long history of country. Forming the largest catchment, fulfil the needs of millions of people for fresh water used in domestic, agriculture, commercial and industrial sectors. Therefore, River Ganga is always the center of attraction to the administrative authorities, institutions, academicians and researchers for its quality issues. The periodically examination of the river water quality for its conservation, restoration or rejuvenation is essential and conducted by many researcher on different quality aspects. The aim of the present investigation is to estimates the spatio-temporal variability in the Ganga River System's hydrology in upstream regions in the Himalayan Region of Uttarakhand state, India. The result clearly explains considerable variation in water quality index (WQI: 29.39-71.60) screening seasonal variation, defining the deterioration of water quality (WQ) of Ganga River from good to moderate polluted level through the overall index of pollution (OIP). Moreover, principal component analysis (PCA) has implied to identify the pollution sources. The PCA generates seven components and contributes $(85.1 \%)$ to influencing river water's hydrochemistry. These outcomes give detailed information to understand the water quality affecting factors in the Ganga River system. The management and remedial practices are an urgent task required to conserve WQ in the upstream region to check WQ's further deterioration in the future.
\end{abstract}

Keywords River Ganga System · Water quality indices · OIP · PCA · Uttarakhand

\section{Introduction}

In the modern era, human civilization is on the edge of a global water catastrophe and facing a serious concern of freshwater pollution. In India's context, around 600 million people are at risk of water stress, and nearly two lakh Indians are dying annually due to the unavailability of potable

Gagan Matta

drgaganmatta@gkv.ac.in

Avinash Kumar

avinashkumar.rs@gkv.ac.in

Anjali Nayak

anjalinayak055@gmail.com

Pawan Kumar

pawan.kumar.gkv@gmail.com

1 Hydrological Research Lab., Research Wing, Department of Zoology and Environmental Science, Gurukula Kangri (Deemed To Be University), Haridwar, India water for drinking (WRI 2019; Matta 2020). River Ganga is one of the major freshwater resources following towards the north-east region of India and sustaining the million of inhibitants (MOEF 2009).

The biodegradable solid waste such as agriculture waste, food wastage and faecal matter of human and animal determined as the organic matter in river water (Finnveden et al. 2009; Stoate et al. 2009). The nutrient (particularly phosphorous and nitrogen) loading in the surface water bodies (e.g. river, lakes) is mainly due to the disposal of municipal sewage water and agricultural wastewater (Tiemeyer et al. 2006; Kumar et al. 2020; Singh et al. 2021), resulting in eutrophication of the river (Matta et al. 2020a, 2020b; Kumar et al. 2021c).

The identification of critical sources of pollution is an essential task for the researchers to manage the available water resources while implementing pollution remedies on surface water bodies like rivers and canals (Khan et al. 2017; Matta et al. 2018a). Quality of freshwater at any particular location of the river system governed by many factors 
like lithology of the river system, anthropogenic activities, atmospheric changes, ecological and climatic conditions (Matta and Kumar 2017a). Climate change is likely to influence the availability of freshwater resources significantly. A study based on 100-year temperature and rainfall datasets determine a declining rainfall trend from 1970 to 2011 in the Uttarakhand Region; this declining trend has become steeper. Besides, the average reduction rate in annual total rainfall was observed and found insignificant, which may lead to significant stress on the state's water resources (Mishra et al. 2015; Matta et al. 2018b; Kumar et al. 2021b). An another long-term appraisal of last 49 year (1971-2020) dataset of water quality parpmeters indicated slight contamination level, and at downstream areas, a decreasing trend in $\mathrm{pH}$ and dissolved oxygen content indicated that the river WQ may fall if the same scenario is repeated in the future (Kumar et al. 2021).

At present, the change in land-use pattern, cropping systems, unsustainable use of resources, changes in agriculture patterns in terms of irrigation, and drainage systems impacting the hydrological cycle of India's various regions and river systems (Gautam and Singh 2015; Matta and Kumar 2017b). Various agencies analyze and plan to retain the river's water quality level in the last three decades. Under the Environment Protection Act, 1986, one of the prominent organizations called the "National Ganga River Basin Authority (NGRBA)" made in 2009 to look after all activities to conserve the aesthetic value of the River Ganga and its tributaries (Kumar et al. 2020). The declining situation in the quality of river water appealed to many investigators' consideration to determine the potential sources of pollution (Tyagi et al. 2013a, b; Bhardwaj et al. 2010; Kumar et al. 2017, 2020). In this regard, various developmental activities (i.e. construction of roads and dams at the upstream region of the Himalayas) and discharge of agricultural wastes in the river reported as critical sources of contaminations (Matta et al. 2018c, 2020c).

The accurate and comprehensive properties of a water system are a major challenge. In recent past decades, many of the water quality indices (WQIs) have been formed and used towards this goal (Tyagi et al. 2013a; Trikoilidou et al. 2017). In this study, a comparison of two different WQIs (WQI by arithmetic mean method and Overall Index of Pollution: OIP) is performed and discussed to portray overall river water quality for human consumption. The suitability of WQI by arithmetic mean method is its usefulness water quality for any intended use as well as in pollution abatement and OIP is largely used specifically under Indian conditions (Trikey et al. 2013).

Thus, depletion in river water and pollution is severe, which was the main focus of the investigation to identify the probable aspects controlling the physicochemical property of water and assessing the suitability of water quality for drinking and other life-supporting activities. In this study, WQI viz., the overall index of pollution (OIP), and environmetrics techniques like principal component analysis (PCA) and cluster analysis (CA) are applied to categorize the WQ of the Ganga river into different quality classes and further identify the sources of pollution. The study could be helpful for the environmentalist, policy planners, and managers to take further necessary steps to conserve the Ganga River's aesthetic values.

\section{Materials and methods}

\section{Study area}

The catchment area of River Ganga System in the North Indian States viz. Uttarakhand and Uttar-Pradesh States is about 2,94,364 sq. km. In contrast, the current study area covered is about $316 \mathrm{~km}$ in the origin state of River Ganga from sampling site- 1 to sampling site-20 during the study (Fig. 1). The upstream site (Gangotri) is a valley-type glacier (NRCD 2009) positioned in the Uttarkashi District of Uttarakhand. River at the downstream site (Roorkee) flows under a canal system, which starts from Haridwar; up to this site, the river receives types of pollutants from the untreated sewage discharge to industrial effluents, wastewater from commercial complexes to solid and liquid waste from significant development and tourist activities (Sharma et al. 2015; Kumar et al. 2021).

\section{Sampling method}

For the study, the total number of 80 samples in triplicate collected (2016-2017) from twenty different sites (Fig. 1 and Table 1) in four different seasons with overall variation observed in temperature ranging from 0 to $46{ }^{\circ} \mathrm{C}$. In pre-monsoon (summer) and monsoon season, the upstream, midstream, and downstream temperatures reported between 20-25 ${ }^{\circ} \mathrm{C}, 25-27^{\circ} \mathrm{C}$, and $27{ }^{\circ} \mathrm{C}$ to $>30^{\circ} \mathrm{C}$. Similarly, during post-monsoon (winter), the temperature at upstream, midstream, and downstream was reported between $13-15{ }^{\circ} \mathrm{C}$, $15-18{ }^{\circ} \mathrm{C}$, and 18 to $>20^{\circ} \mathrm{C}$, respectively (CWC 2012). Geocoordinates during the sampling for locations recorded using GPSMAP (GARMIN) device model no.: 60CSx (Made in Taiwan). The variation observed in temperature ranging from 0 to $46{ }^{\circ} \mathrm{C}$. The collection of water samples done in pre-acid-washed Nalgene Wide-Mouth Natural HDPE polypropylene, $1,000 \mathrm{ml}$ bottles. The WQ parameters like conductivity (cond.), temperature (temp.), dissolved oxygen (DO) were measured on-site using the potable multi-parameter instrument, model no: HQ40D and DR1900 (HACH). For other WQ parameters (e.g. TS, TDS, TSS, BOD, COD, $\mathrm{Cl}, \mathrm{P}, \mathrm{TKN}$, hardness, acidity, alkalinity, sulphate, etc.), the 


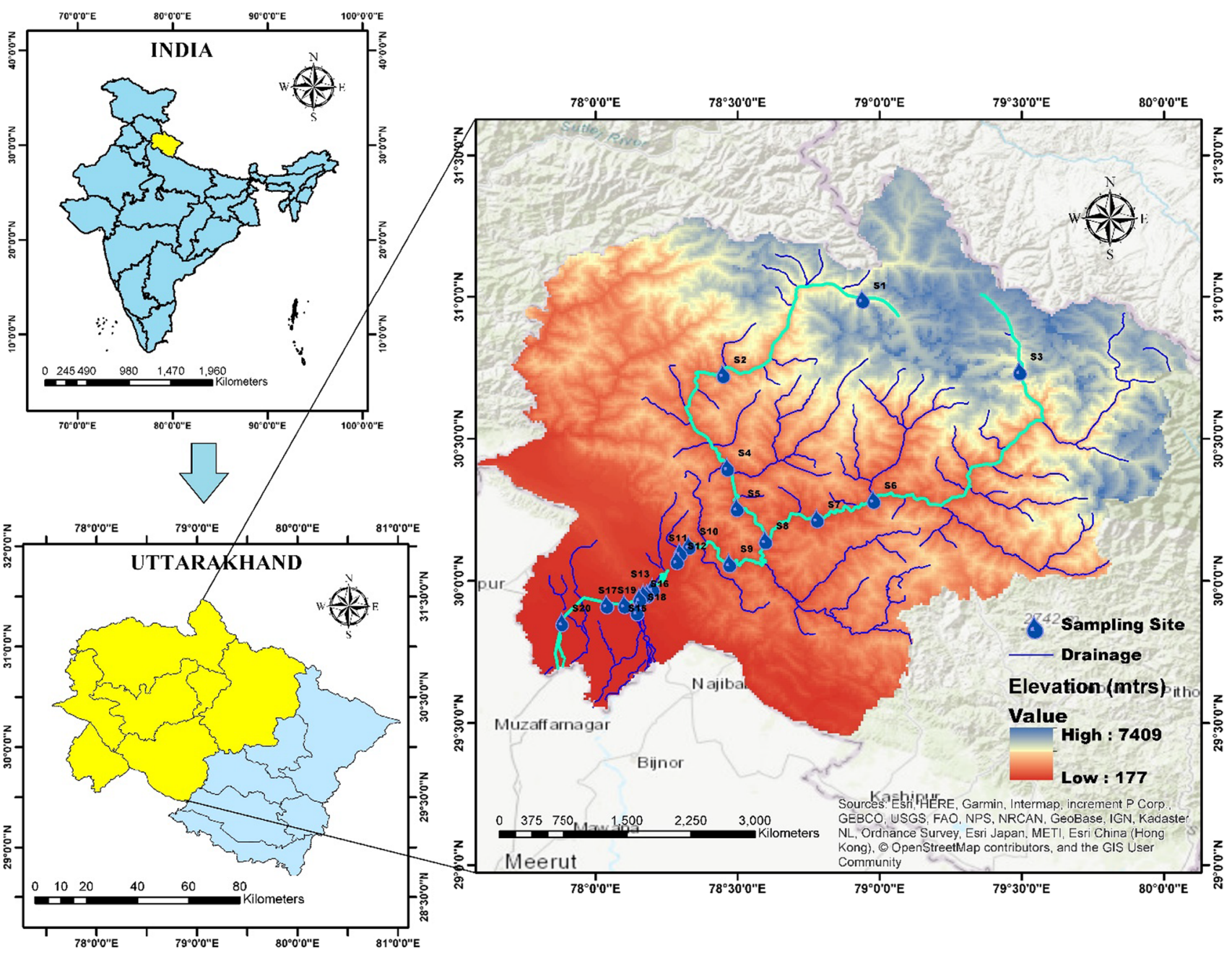

Fig. 1 Location map of study area with monitoring station of Ganga River System

river water samples are tested in the laboratory, and further analysis was conducted by following the standard methods (APHA 2012). For sulphate and phosphate measurements, a colourimetric analysis carried out using UV Spectrophotometer Cary 60 (USEPA 2000; Matta et al. 2018d).

\section{Water quality index}

Numerous water quality indices (WQIs) are available and applied recently for complex and large datasets of various river basins to understand the water quality of river systems. In this study, the arithmetic means method adopted to assess the water quality into four rating scales of probable pollution level.

The WQ Indexing equation (Eq. 1):

$\mathrm{WQI}=\sum_{i=0}^{n} \frac{W_{i} q_{i}}{W_{i}}$ where $q_{i}=$ sub-index or quality rating for the ith parameter.

$W_{i}=$ unit weight for the ith parameter.

The calculation of WQI involves four steps: first, the selection of parameters; in this study, 14 hydro-chemical variables were selected out of 19 due to the lack of proposed permissible limit of drinking water (WHO 2011; BIS 2012); second, computation of sub-index or quality rating (qi); the equation (Eq. 2) expressed as (Brown et al. 1972):

$q_{i}=\left\{\frac{\left(V_{a}-V_{i}\right)}{\left(V_{s}-V_{i}\right)}\right\} \times 100$

$q_{i}=$ sub-index for the ith parameter; $V_{a}=$ actual value present of the ith parameter at a given sampling station.

$V_{i}=$ ideal value for the ith parameter.

$V_{s}=$ standard value for the ith parameter.

Suppose quality rating $=$ zero that means the complete absence of pollutants. While quality rating $0<q_{i}<100$ 
Table 1 Details of Sampling Site along Ganga River system with their geo-coordinated

\begin{tabular}{|c|c|c|c|c|c|}
\hline $\begin{array}{l}\text { Sam- } \\
\text { pling } \\
\text { Site No }\end{array}$ & Labels & Sampling Site & Type of system & Latitude & Longitude \\
\hline 1 & S1 & Gangotri & River system & $30^{\circ} 49^{\prime} 59.99^{\prime \prime} \mathrm{N}$ & $79^{\circ} 10^{\prime} 0.00^{\prime \prime} \mathrm{E}$ \\
\hline 2 & S2 & Uttarkashi & River system & $30^{\circ} 43^{\prime} 48.00^{\prime \prime} \mathrm{N}$ & $78^{\circ} 27^{\prime} 0.00^{\prime \prime} \mathrm{E}$ \\
\hline 3 & S3 & Badrinath & River system & $30^{\circ} 43^{\prime} 48.00^{\prime \prime} \mathrm{N}$ & $79^{\circ} 28^{\prime} 48.00^{\prime \prime} \mathrm{E}$ \\
\hline 4 & S4 & Tehri Dam & River system & $30^{\circ} 22^{\prime} 23.99^{\prime \prime} \mathrm{N}$ & $78^{\circ} 28^{\prime} 29.99^{\prime \prime} \mathrm{E}$ \\
\hline 5 & S5 & Koteshwar & River system & $30^{\circ} 15^{\prime} 30.13^{\prime \prime} \mathrm{N}$ & $78^{\circ} 29^{\prime} 46.84^{\prime \prime} \mathrm{E}$ \\
\hline 6 & S6 & Rudraprayag & River system & $30^{\circ} 16^{\prime} 48.00^{\prime \prime} \mathrm{N}$ & $78^{\circ} 58^{\prime} 48.00^{\prime \prime} \mathrm{E}$ \\
\hline 7 & S7 & Srinagar & River System & $30^{\circ} 13^{\prime} 17.03^{\prime \prime} \mathrm{N}$ & $78^{\circ} 46^{\prime} 48.16^{\prime \prime} \mathrm{E}$ \\
\hline 8 & S8 & Devprayag & River system & $30^{\circ} 8^{\prime} 46.12^{\prime \prime} \mathrm{N}$ & $78^{\circ} 35^{\prime} 54.91^{\prime \prime} \mathrm{E}$ \\
\hline 9 & S9 & Byasi, Rishikesh & River system & $30^{\circ} 3^{\prime} 53.50^{\prime \prime} \mathrm{N}$ & $78^{\circ} 28^{\prime} 21.44^{\prime \prime} \mathrm{E}$ \\
\hline 10 & $\mathrm{~S} 10$ & Lakshman Zhoola, Rishikesh & River system & $30^{\circ} 7^{\prime} 34.79^{\prime \prime} \mathrm{N}$ & $78^{\circ} 19^{\prime} 46.85^{\prime \prime} \mathrm{E}$ \\
\hline 11 & S11 & Triveni Ghat, Rishikesh & River system & $30^{\circ} 6^{\prime} 10.90^{\prime \prime} \mathrm{N}$ & $78^{\circ} 17^{\prime} 55.00^{\prime \prime} \mathrm{E}$ \\
\hline 12 & $\mathrm{~S} 12$ & Pashulok Barrage, Rishikesh & River system & $30^{\circ} 4^{\prime} 29.84^{\prime \prime} \mathrm{N}$ & $78^{\circ} 17^{\prime} 14.65^{\prime \prime} \mathrm{E}$ \\
\hline 13 & S13 & Chilla Power House, Rishikesh & River system & $29^{\circ} 58^{\prime} 36.35^{\prime \prime} \mathrm{N}$ & $78^{\circ} 12^{\prime} 8.04^{\prime \prime} \mathrm{E}$ \\
\hline 14 & S14 & Bhimgoda Barrage, Haridwar & River/canal system & $29^{\circ} 57^{\prime} 23.30^{\prime \prime} \mathrm{N}$ & $78^{\circ} 10^{\prime} 58.27^{\prime \prime} \mathrm{E}$ \\
\hline 15 & S15 & Har-Ki-Pauri, Haridwar & Canal system & $29^{\circ} 57^{\prime} 18.83^{\prime \prime} \mathrm{N}$ & $78^{\circ} 10^{\prime} 14.46^{\prime \prime} \mathrm{E}$ \\
\hline 16 & S16 & Mayapur, Haridwar & Canal system & $29^{\circ} 56^{\prime} 31.55^{\prime \prime} \mathrm{N}$ & $78^{\circ} 9^{\prime} 20.65^{\prime \prime} \mathrm{E}$ \\
\hline 17 & S17 & Jatwara Bridge, Haridwar & Canal system & $29^{\circ} 55^{\prime} 9.74^{\prime \prime} \mathrm{N}$ & $78^{\circ} 6^{\prime} 12.83^{\prime \prime} \mathrm{E}$ \\
\hline 18 & S18 & Missarpur Village, Haridwar & River system & $29^{\circ} 53^{\prime} 42.60^{\prime \prime} \mathrm{N}$ & $78^{\circ} 8^{\prime} 46.92^{\prime \prime} \mathrm{E}$ \\
\hline 19 & S19 & Bahadrabad, Haridwar & Canal system & $29^{\circ} 55^{\prime} 11.72^{\prime \prime} \mathrm{N}$ & $78^{\circ} 2^{\prime} 26.47^{\prime \prime} \mathrm{E}$ \\
\hline 20 & S20 & Roorkee & Canal system & $29^{\circ} 51^{\prime} 23.89^{\prime \prime} \mathrm{N}$ & $77^{\circ} 53^{\prime} 0.43^{\prime \prime} \mathrm{E}$ \\
\hline
\end{tabular}

implies that the pollutants are above the standards (Ahmad 2014).

The third step is calculating unit weight $\left(W_{i}\right)$ (Eq. 3) for the ith parameter, which is inversely proportional to the standard value of that particular variable.

$W_{i}=\frac{k}{S_{i}}$

where $S_{i}=$ standard value for the ith parameter.

$k=$ proportionality constant, which calculated as (Eq. 4):

$k=\frac{1}{\sum \frac{1}{S_{i}}}$

Step four is to categorize computed WQI values into five classes for WQ given as $0-25$ is excellent (E); 26-50 is $\operatorname{good}(\mathrm{G}) ; 51-75$ is moderately polluted $(\mathrm{M}) ; 76-100$ is severely polluted (S), and $>100$ is unfit (U) for drinking purposes (Banerjee and Srivastava 2009).

\section{Overall index of pollution}

The health condition of freshwater assessed with the applicability of the overall index of pollution (OIP), calculated as middling of pollution index $\left(P_{i}\right)$ for individual variables and expressed by the following mathematical formula (Eq. 5):

$\mathrm{OIP}=\frac{\sum_{i=1} P_{i}}{n}$

$P_{i}$ estimated by converting the measured concentration into numerical value through various mathematical expressions (Table 2) for individual variables, and ' $n$ ' represents the considered number of parameters. The adopted OIP classification scheme proposed as $0-1$ for excellent (class C1), 1-2 for acceptable (class C2), 2-4 for slightly polluted

Table 2 Mathematical expressions for function curves for considered parameters in OIP calculation

\begin{tabular}{llll}
\hline Sr. No & Parameter & $\begin{array}{l}\text { Range of con- } \\
\text { centration }\end{array}$ & Mathematical expressions \\
\hline 1 & Turbidity & $10-500$ & $x=(y+43.9) / 34.5$ \\
2 & TDS & $\leq 500$ & $x=1$ \\
3 & BOD & $2-30$ & $x=y / 1.5$ \\
4 & Hardness & $75-500$ & $\exp (y+42.5) / 205.58$ \\
5 & Chloride & $\leq 150$ & $x=1$ \\
6 & Sulphate & $\leq 150$ & $x=1$ \\
\hline
\end{tabular}


(class C3), 4-8 for polluted (class C4), and 8-16 for heavily polluted (class C5) (Sargaonkar and Deshpandey 2003).

\section{Environmetrics}

The term "environmetrics" used for multivariate statistical analysis like PCA to quantify the significance of variables that describes the evaluated grouped data set and patterns of the internal characteristics of the sampling locations. PCA used to explain the reduced set of observed variables from orthogonal (non-correlated) variables. Many researchers used these methodologies to characterize and appraise the freshwater and sediment quality (Sargaonkar and Deshpandey 2003; Mishra et al. 2015; Herojeet et al. 2016). Kaiser-Meyer-Olkin (KMO) and Bertlett's tests were used to determine whether the dataset was suitable for PCA. Communalities values $>0.5$ were used to test the variable selection for PCA. To ensure that the dataset was normal, another preliminary assumption test (Kolmogorov-Smirnov: KS and Shaphiro-Wilk: SW) was performed (Kumar et al. 2021a).

Principal component analysis (PCA) derived hidden linear relationships from a data set of variables about the possible effects on hydrochemistry (Osei et al. 2010). PCA is a method that provides an analytical procedure whereby an original dataset containing factors reconstructed to a reduced set of new factors. PCA can obtain the information related to a particular variable with the most negligible loss of the entire data set (Simeonov et al. 2003). To attain this, converting the new set of uncorrelated factors and assembling most of the variation the first few present in an extensive data set of original variables. The data matrix values were standardized based on the correlation matrix between each variable before statistical analysis (Singh et al. 2004), considering the variables equally and ensuring that no parameter of different units with higher absolute values dominates the
PCA. The PCs formed in a successively order with reducing influences to the variance, i.e. variations present in the original data explained by the first principal component (PC1), and decreasing proportions of the variance accounted by successive principal components (Simeonov et al. 2004; Vieira et al. 2012).

\section{Results and discussion}

For the study's course, samples assessment of freshwater in the Ganga River System in terms of physicochemical parameters seasonally represented in Table S1 and Table S2. The descriptive statistics for the nineteen parameters for all the monitoring locations throughout the study presented in Table 3. The seasonally observed variation in dataset was primarily compared with their respective standard acceptable values of BIS (Bureau Of Indian Standards) for drinking purpose. Considerably, the recorded concentration of TU was found above their acceptable limit all the monitoring locations during the study period which indicated the sedimentation load makes the river water more turbid. The LI (light intensity) value ranged from 321.67 to 5652.85 ( $\mu$ mol. m-2 s-1) with mean of $1956.84 \mu$ mol. m- 2 s- 1 at all studied locations. The LI helps to indicate the biological and chemical process in the water body, and an increase in turbidity implies a massive reduction in light for phytoplankton (Singh et al. 2005; Lionard et al. 2005; Matta et al. 2020b). The temperature variation observed from 13 to $29{ }^{\circ} \mathrm{C}$, with a mean value of $20.44^{\circ} \mathrm{C}$. Similar observations found during the study of a tributary of River Ganga (Matta et al. 2020a).

The conductivity, turbidity, and velocity varied from 96.45 to 131.57 ( $\mu \mathrm{mhos} / \mathrm{Cm}^{2}$ ), 16.79-376.46 NTU, and $0.56-1.23 \mathrm{~m} / \mathrm{s}$ during the study period. In river water, the average concentration of solids, TS, TSS, and TDS was

Table 3 Descriptive statistics for study area along with standard limits proposed by BIS (2012)

\begin{tabular}{|c|c|c|c|c|c|c|c|c|c|c|c|}
\hline Parameters & $\begin{array}{l}\text { LI } \\
\left(\mu \text { mol. } \mathrm{m}^{-2} \mathrm{~s}^{-}\right.\end{array}$ & & $\begin{array}{l}\text { Temp } \\
\left({ }^{0} \mathrm{C}\right)\end{array}$ & $\begin{array}{l}\text { Cond } \\
\left(\mu \mathrm{mhos} / \mathrm{Cm}^{2}\right)\end{array}$ & $\begin{array}{l}\text { Turbidity } \\
\text { (NTU) }\end{array}$ & $\begin{array}{l}\text { Vel } \\
(\mathrm{m} / \mathrm{s})\end{array}$ & $\begin{array}{l}\text { T.S } \\
(\mathrm{mg} / \mathrm{L})\end{array}$ & $\begin{array}{l}\text { T.S.S } \\
(\mathrm{mg} / \mathrm{L})\end{array}$ & $\begin{array}{l}\text { T.D.S } \\
\text { (mg/L) }\end{array}$ & $\begin{array}{l}\mathrm{DO} \\
(\mathrm{mg} / \mathrm{L})\end{array}$ & $\begin{array}{l}\mathrm{BOD} \\
(\mathrm{mg} / \mathrm{L})\end{array}$ \\
\hline Mini & 321.67 & & 13 & 96.45 & 16.79 & 0.56 & 46 & 18.16 & 5.01 & 7.1 & 3.2 \\
\hline $\operatorname{Max}$ & 5652.85 & & 29 & 131.57 & 376.46 & 1.23 & 3001.96 & 2707.28 & 294.68 & 10.5 & 5.8 \\
\hline Mean & 1956.84 & & 20.44 & 116.6 & 161.13 & 0.86 & 579.25 & 504.34 & 71.19 & 8.83 & 4.52 \\
\hline SD & 869.32 & & 4.24 & 9.81 & 105.82 & 0.14 & 708.27 & 636.54 & 73.65 & 0.79 & 0.63 \\
\hline BIS STD & - & & - & - & 5 & - & - & - & 2000 & - & - \\
\hline Parameters & $\begin{array}{l}\text { COD } \\
(\mathrm{mg} / \mathrm{L})\end{array}$ & $\begin{array}{l}\text { Free } \\
(\mathrm{mg} /\end{array}$ & & $\begin{array}{l}\text { Alkalinity } \\
(\mathrm{mg} / \mathrm{L})\end{array}$ & $\begin{array}{l}\text { Hardness } \\
(\mathrm{mg} / \mathrm{L})\end{array}$ & $\begin{array}{l}\text { Acidity } \\
(\mathrm{mg} / \mathrm{L})\end{array}$ & $\begin{array}{l}\mathrm{Cl} \\
(\mathrm{mg} / \mathrm{L})\end{array}$ & $\begin{array}{l}\mathrm{P} \\
(\mathrm{mg} / \mathrm{L})\end{array}$ & $\begin{array}{l}\text { TKN } \\
(\mathrm{mg} / \mathrm{L})\end{array}$ & \multicolumn{2}{|c|}{ Sulphate $(\mathrm{mg} / \mathrm{L})$} \\
\hline Mini & 5.14 & 0.1 & & 109 & 112.5 & 26.51 & 5.01 & 0.23 & 0 & \multicolumn{2}{|l|}{8.64} \\
\hline Max & 9.72 & 1.9 & & 223 & 256 & 60.32 & 13.21 & 0.9 & 0.1 & \multicolumn{2}{|l|}{22.9} \\
\hline Mean & 6.47 & 0.67 & & 178.42 & 172.77 & 43.16 & 7.81 & 0.57 & 0.04 & \multicolumn{2}{|l|}{18.54} \\
\hline SD & 1.01 & 0.35 & & 26.36 & 30.03 & 8.17 & 1.37 & 0.18 & 0.02 & \multicolumn{2}{|l|}{3.06} \\
\hline BIS STD & - & - & & 600 & 600 & & 1000 & & & \multicolumn{2}{|l|}{400} \\
\hline
\end{tabular}


$579.25,504.34$, and $71.19 \mathrm{mg} / \mathrm{L}$, representing the sediment load during the monsoon season transported from the watersheds. A maximum amount of total dissolved solids may be present due to the soil and clay particles (Daphne et al. 2011). The concentration of oxygen and its consumption level observed in COD, DO, and BOD, with an average value of $8.33,4.52$, and $6.47 \mathrm{mg} / \mathrm{L}$ throughout the study period. The observation of free $\mathrm{CO}_{2}$ levels also helped to understand the respiration process and a living planktonic community (Matta and Uniyal 2017). The reported mean concentration of free $\mathrm{CO}_{2}$ was $0.67 \mathrm{mg} / \mathrm{L}$ throughout the study period.

The minimum and maximum concentration of alkalinity (109-223 mg/L), total hardness (112.5-256 mg/L), and acidity (26.51-60.32 mg/L) throughout the study period determines the discharge of domestic and industrial sewage, which contributes to the accumulation of large quantities of alkaline ions into the river water. Mean nutrient concentrations occur in the order $\mathrm{SO}_{4}>\mathrm{Cl}^{-}>\mathrm{PO}_{3}{ }^{-4}>\mathrm{TKN}$ (Total Kjeldahl Nitrogen). The sulphate concentration ranges between 8.64 and $22.9 \mathrm{mg} / \mathrm{L}$, whereas chloride, phosphate, and TKN concentration ranging between 5.01 and $13.21 \mathrm{mg} / \mathrm{L}, 0.23-0.9 \mathrm{mg} / \mathrm{L}$, and $0-0.1 \mathrm{mg} / \mathrm{L}$, respectively. These nutrients present naturally in surface water, sulphate and chloride give taste to water, but excessive amounts make it unfit to drink. Phosphate and TKN essential for the growth of aquatic plants, which gives food and habitat for organisms like fish and microorganisms (Matta et al. 2015a; McCarthy 2004; Tare et al. 2003).

\section{Multivariate statistical analysis}

The KMO test value $(0.69, p=0.00)$ was close to 1 , indicating that the dataset was suitable for PCA. The Q-Q plot and the test values of KS and SW $(p<0.05)$ demonstrated that the data distribution was not normal. The communalities had values greater than 0.5 in all of the parameters. As a result, the water quality data from 20 separate places may be summed up into an eight-variable data set. The original mean dataset's variability was characterized by a screen plot (Fig. 2), determining seven variables, contributing $85.1 \%$ of cumulative variance for the water quality at 20 different sampling locations. On the eigenvalue criteria (Pathak and Limaye 2011; EPA 2012), three principal components (PCs) identified by varimax normalized rotation as essential as their eigenvalues are found higher than one and their variability was observed $>10 \%$.

The factor weights values of assessed factors concerning three PCs signified in Table 4. Further, it found that PC1 showed $29.4 \%$ of total variance included a significant part of the variables connected to temperature, conductivity, turbidity, $\mathrm{Cl}^{-}$, TKN, P, solids, and dissolved oxygen. The variables temperature $(0.75)$, conductivity $(0.68)$, turbidity (0.83), chlorides (0.61), TKN (0.84 and P (0.72) had a positive factor, whereas the solids and DO having a negative factor weight in the development of PC1 (Table 4). The loading weight of PC1 indicated that the consumption of oxygen by the dissolved organic matter or pollutants, which could be linked to domestic wastewater, municipal point source effluents and agricultural non-point source runoff (Simeonov 2003; Mishra 2010). On the other hand, PC2 explained $16.7 \%$ of total variance and found with a positive weight with free $\mathrm{CO}_{2}$ (0.79) only. Moreover, BOD (0.76) and DO ( -0.65$)$, variables had negative weight, while TKN (0.76) and sulphate's $(0.824)$ weight was positive to form PC3 with total variability of $10.6 \%$. The factor weights of the PCA observations indicated the elevation difference, geogenic input, rainfall runoff from mountainous locations,
Fig. 2 Screen plot of the eigenvalue for each component

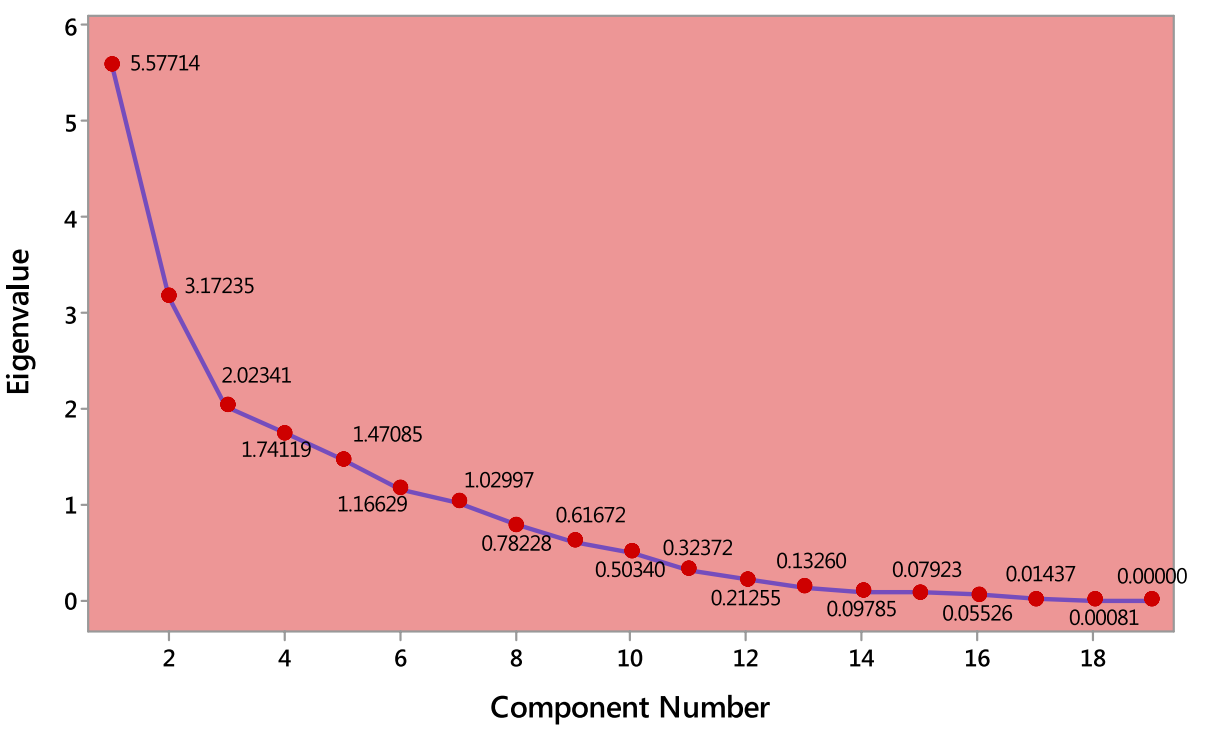


Table 4 Factor matrix obtained by the method of principal components analysis

\begin{tabular}{lclc}
\hline Parameters & \multicolumn{3}{c}{ Principal components } \\
\cline { 2 - 4 } & PC1 & PC2 & PC3 \\
\hline LI & 0.079 & -0.330 & 0.338 \\
Temperature & 0.746 & 0.107 & 0.217 \\
Conductivity & 0.680 & 0.037 & -0.145 \\
Turbidity & 0.833 & -0.105 & 0.076 \\
Velocity & 0.178 & -0.316 & -0.268 \\
TS & -0.730 & 0.040 & 0.154 \\
TSS & -0.629 & 0.029 & 0.159 \\
TDS & -0.638 & 0.133 & 0.094 \\
DO & -0.715 & -0.203 & -0.646 \\
BOD & 0.114 & -0.249 & 0.759 \\
COD & 0.173 & -0.153 & -0.211 \\
Free CO & \\
Alkalinity & 0.117 & 0.792 & 0.177 \\
Hardness & -0.068 & -0.149 & 0.292 \\
Acidity & 0.165 & 0.199 & 0.275 \\
Cl & -0.075 & -0.172 & 0.030 \\
P & 0.610 & -0.363 & -0.022 \\
TKN & 0.720 & 0.387 & -0.232 \\
Sulphate & 0.835 & 0.293 & 0.763 \\
\% of total variation & 0.748 & 0.096 & 0.824 \\
Cumulative \% of total variation & 29.4 & 46.0 & 56.7 \\
\hline & & & \\
& 29.4 & 16.7 & 10.6 \\
& & &
\end{tabular}

agricultural waste from urban and semi-urban areas, developmental activities and biochemical processes as main sources of these variables (temp., TU, TS, TDS, TSS, DO, $\mathrm{BOD}$, free $\mathrm{CO}_{2}, \mathrm{Cl}^{-}$, TKN, $\mathrm{P}$ and sulphates) to reflect the overall water quality (Fig. 3).

\section{Interpretation of WQIs}

The value of WQI for all selected sites during all seasons varying in WQI of selected 20 sampling locations and the riverbank in Uttarakhand state, India, is illustrated in Table 5 and graphically represented in Figure S1. The results define temporal and spatial changes in water quality and reveal a specific trend of vacillations among different seasons. Index value helped to detect water quality at different sites; based on it, site-5 (WQI: 52.25), site-13 (WQI: 51.57), and site-16 (WQI: 56.28) show the moderate quality, and the rest of the sites were in a good quality class. During the seasonal index calculation, water samples collected at the Bahadrabad town (sampling site 19) observed with the highest WQI (71.6) in monsoon season, signifying moderate pollution in river water (as per rating scale of WQI). Except for sampling locations 2, 3, $5,13,16,18$, and 20 , the rest of all sampling locations exhibit good to excellent water quality in winter and postmonsoon seasons.

On the other hand, OIP also calculated for different seasons and individual monitoring locations. The average values of six parameters (turbidity, TDS, BOD, harness, chloride, and sulphate) were used along with their mathematical expression to estimate the individual pollution index (Pi) (Table 6). The mean of integrated Pi gave a final numerical value, represents OIP. The observed values of OIP claimed the river water quality in class $\mathrm{C} 3$ at most of the monitoring sites, which indicated slightly polluted conditions as OIP ranged from 2 to 4 . Only sites 4 and 17 showed class C2 (OIP: 1-2), representing the acceptable condition (Table 5). The seasonal assessment also represents the degraded water quality of the river in various seasons. The $\mathrm{C} 2$ class was observed at seven monitoring locations during summer, whereas six locations were
Fig. 3 Dendrogram of spatial similarities between monitoring stations formulated by CA

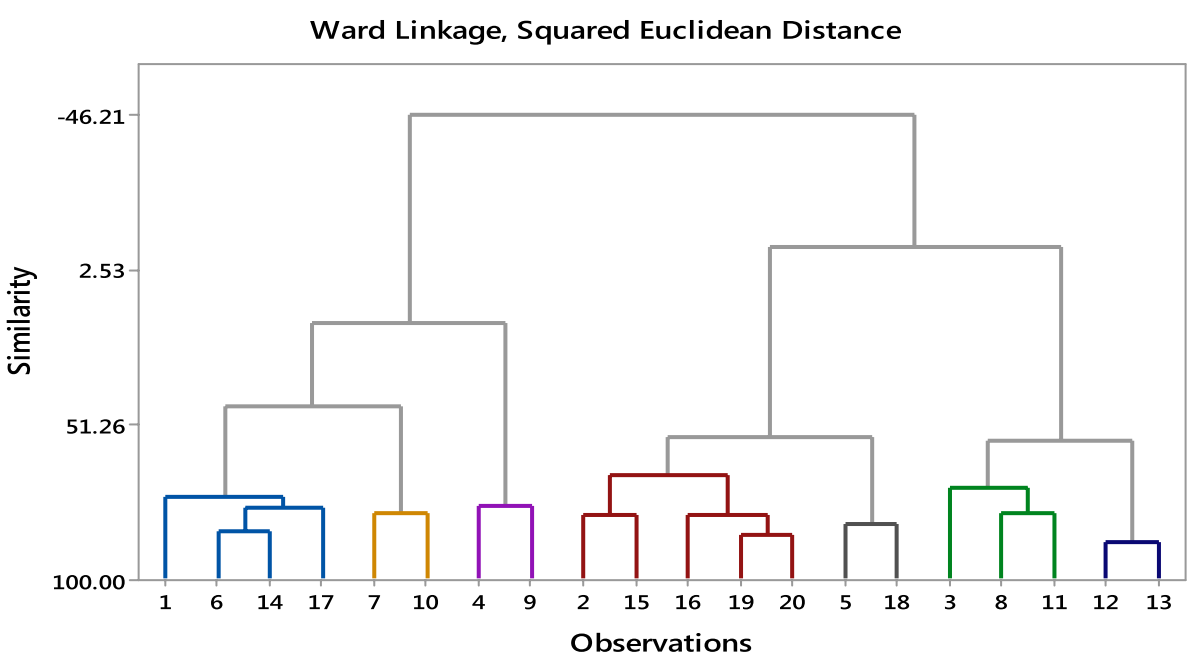


Table 5 Site-wise water quality indexing

\begin{tabular}{llllllllll}
\hline \multicolumn{2}{l}{ Site-Wise WQI } & & & & & & & & \\
\hline Sites & WQI's & Quality Status & OIP & Class & Sites & WQI's & Quality Status & OIP & Class \\
\hline S1 & 44.2 & G & 2.2 & C3 & S11 & 43.75 & G & 2.41 & C3 \\
S2 & 43.2 & & 2.27 & & S12 & 48.94 & & 2.86 & \\
S3 & 48.8 & & 2.99 & & S13 & 51.57 & M & 3.02 & \\
S4 & 43.59 & & 1.85 & C3 & S14 & 38.19 & G & 2.2 & \\
S5 & 52.25 & M & 3 & C3 & S15 & 41.05 & & 2.37 & \\
S6 & 41.03 & G & 2.34 & & S16 & 56.28 & M & 2.92 & \\
S7 & 41.89 & & 2.04 & & S17 & 33.35 & G & 1.75 & C2 \\
S8 & 49.69 & & 2.93 & & S18 & 49.91 & & 2.91 & C3 \\
S9 & 49.55 & & 2.09 & & S19 & 49.9 & & 2.51 & \\
S10 & 42.74 & & 2.06 & & S20 & 49.43 & & 2.64 & \\
\hline
\end{tabular}

under acceptable conditions during the post-monsoon season. During the winter and monsoon season, class C3 reported at most of the sampling locations. The seasonal OIP is represented graphically in Figure S2. Researchers of different life works have applied OIP to represent the health of various rivers flowing in India (Shukla et al. 2017; Dhawde et al. 2018).

\section{Policy issues and recommendations}

In the recent time, the country like India is facing scarcity of water quality. The availability of clean and fresh water has become a critical concern for the health and hygiene of human beings as well as other living organisms. River Ganga sustains a major population of India by providing water for agricultural, industrial and domestic activities. The current government is very much concern and putting very much efforts to maintain its quality by approving an integrated conservation mission (Namami Gange Programme) in June 2014 with budget 20 thousand crore for pollution abatement, conservation and rejuvenation. The river water quality is getting affected by the big drains bringing waste into it, developmental activities, change in nutrient level and many other forms which may have serious negative influence on human health as well as flora and fauna those consume river water directly or indirectly. This is a serious matter of concern for conservators or policy makers to reduce the bad impacts, protect and conserve river water judiciously. To assess the impacts of change in river water quality on human lives, different hydrochemical parameters are evaluated for diversified used from human consumption to agriculture; from commercial to industrial. Therefore, it is recommended that a rapid cost-effective in situ and laboratory analysis is required to determine the weather river water is safe or unfit for use. If the quality comes under the polluted category, there should be proper management and restoration steps followed to prevent human and environment before dumping of debris, effluents and sewage into the river system. There is a need of more studies or tools for river basin to monitor the main quality parameters and sources of contaminations in river water. Hence, it is suggested that issue-based studies should be conducted into account for resolving the pollution problems. In addition to it, the hard core locations must be assessed by advanced and modern techniques to identify and control the sources of pollution.

\section{Conclusions}

The outcome of the present study conducted on the Ganga River System, covering twenty sampling stations with the applicability of a comparative WQI, and PCA) to categorization water quality into diverse classes of quality, estimation of potential pollution sources that influence the hydrochemistry. The present study clearly defines the valuable information through different indices and multivariate statistical techniques in probing and amplifying compound data sets, recognizing contamination causes, and understanding variations in water quality to better design action plans for river rejuvenation. PCA identified the chief variable or sources responsible for variation in water quality. Results clearly show that the critical source of river water deprivation is the emancipation of domestic sewage wastewater, waste from developmental activities and agricultural wastes at the down-sites of River Ganga and contamination from local villages into the river water. The rejuvenation should diminish livestock activities around the river; otherwise, pollution can affect the human population and all living forms and reduce 


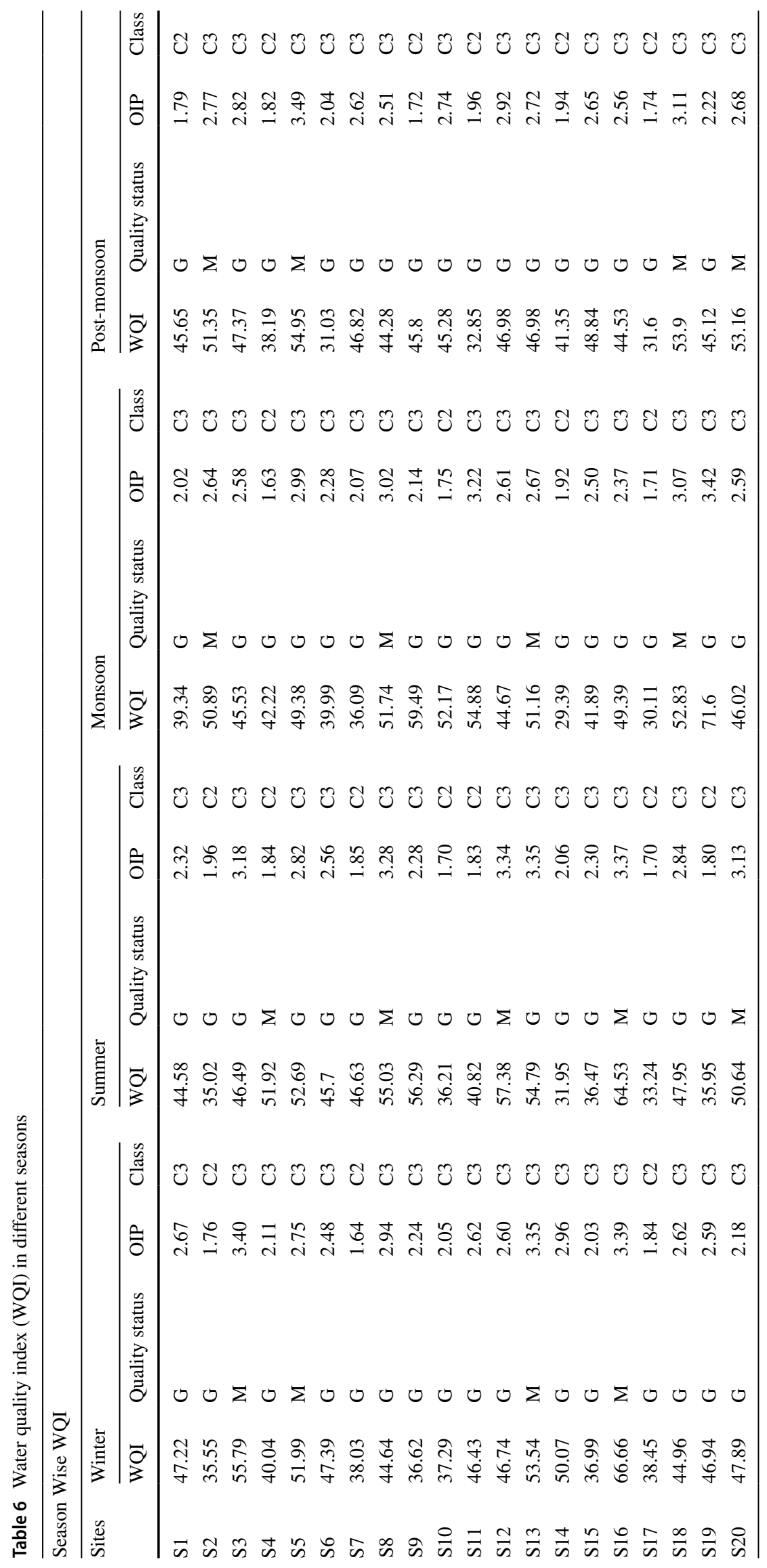


socio-economic and environmental disasters like climate change. These determinations should have considered for future planning and management of the Ganga River and its tributaries.

Supplementary Information The online version contains supplementary material available at https://doi.org/10.1007/s13201-021-01552-9.

Acknowledgements The facility of instrumentation and workspace for this research article supported by the Department of Zoology and Environmental Science, Gurukul Kangri (Deemed to be University), Haridwar, Uttrakhand (India).

Author contributions GM: Concept, supervision, methodology, writing (drafting and finalizing); AK: formal analysis, indexing, software; AN: indexing and laboratory analysis; PK: Fieldwork and sample collection; MA: policy and science communication.

Funding The author(s) received no specific funding for this work.

Data availability There is no additional data is available related to any published article or repository.

\section{Declarations}

Conflict of interest The authors declare no conflict of interest.

Open Access This article is licensed under a Creative Commons Attribution 4.0 International License, which permits use, sharing, adaptation, distribution and reproduction in any medium or format, as long as you give appropriate credit to the original author(s) and the source, provide a link to the Creative Commons licence, and indicate if changes were made. The images or other third party material in this article are included in the article's Creative Commons licence, unless indicated otherwise in a credit line to the material. If material is not included in the article's Creative Commons licence and your intended use is not permitted by statutory regulation or exceeds the permitted use, you will need to obtain permission directly from the copyright holder. To view a copy of this licence, visit http://creativecommons.org/licenses/by/4.0/.

\section{References}

Ahmad AB (2014) Evaluation of Groundwater Quality Index for drinking purpose from some villages around Darbandikhan district, Kurdistan Region-Iraq. IOSR J Agric Veterinary Sci 7:34-41

American Public Health Association (APHA) (2012) Standard methods of water and wastewater analysis, 22nd edn. American Public Health Association, Washington DC

Banerjee T, Srivastava RK (2009) Water quality index for surface water quality assessment. Water Sci Technol 60:8

Bhardwaj V, Singh DS, Singh AK (2010) Water quality of the Chhoti Gandak River using principal component analysis, Ganga Plain, India. J Earth Syst Sci 119(1):117-127

BIS (Bureau of Indian Standards) (1972) (2012) Specification for drinking water IS 10500: 2012, New Delhi, India

Brown RM, McLellend NI, Deininger RA, O'Connor MFA (1972) Water quality index crashing the psychological barrier. Indic Environ Quality 1:173-182

Central Water Commission (CWC) (2012) Environmental evaluation study of Ramganga major irrigation project. Central Water Comm 1:16
Daphne LHX, Utoma HD, Kenneth LZH (2011) Correlation between turbidity and total suspended solids in Singapore canals. J Water Sust 1:313-322

Dhawde R, Surve N, Macaden R (2018) Physicochemical and bacteriological analysis of water quality in drought prone areas of Pune and Satara Districts of Maharashtra, India. Environments. https:// doi.org/10.3390/environments5050061

Environment Protection Agency (EPA) (2012) A report on Water: Monitoring and Assessment". United states Environmental Protection Agency. Retrieved from USEPA website http://water.epa. gov/type/rs1/monitoring/vms55.cfm

Finnveden G, Hauschild MZ, Ekvall T, Guinee J, Heijungs R, Hellweg S, Koehler A, Pennington D, Suh S (2009) Recent developments in life cycle assessment. J Environ Manag 91(1):1-21

Gautam M, Singh AK (2015) Impact of climate change on water resources. In: Singh A, Dagar J, Arunachalam A, Gopichandran $\mathrm{R}$, Shelat K (eds) Climate change modelling, planning and policy for agriculture. Springer, New Delhi

Herojeet RK, Rishi MS, Lata R, Sharma R (2016) Application of environmetrics statistical models and water quality index for groundwater quality characterization of alluvial aquifer of Nalagarh Valley, Himachal Pradesh. India Sustain Water Resour Manag 2:39-53. https://doi.org/10.1007/s40899-015-0039-y

Khan MYA, Gani KM, Chakrapani GJ (2017) Spatial and temporal variations of physicochemical and heavy metal pollution in Ramganga River - a tributary of River Ganges, India. Environ Earth Sci 76:231. https://doi.org/10.1007/s12665-017-6547-3

Kumar A, Taxak AK, Sharma MP (2017) Analysis of water environment changing trend in Bhagirathi tributary of Ganges in India. Desalin Water Treat 63:55-62

Kumar A, Mishra S, Taxak AK, Pandey R, Yu Z-G (2020) Nature rejuvenation: long-term (1989-2016) vs short-term memory approach based appraisal of water quality of the upper part of Ganga River, India. Environ Technol Innov 20:101164. https:// doi.org/10.1016/j.eti.2020.101164

Kumar A, Taxak AK, Mishra S, Pandey R (2021) Long term trend analysis and suitability of water quality of River Ganga at Himalayan hills of Uttarakhand, India. Environ Technol Innov 22:101405. https://doi.org/10.1016/j.eti.2021.101405

Kumar A, Matta G, Bhatnagar S (2021a) A coherent approach of water quality indices and multivariate statistical models to estimate the water quality and pollution source apportionment of River Ganga System in Himalayan region, Uttarakhand, India. Environ Sci Pollut Res 28:42837-42852. https://doi.org/10. 1007/s11356-021-13711-1

Kumar A, Jigyasu DK, Kumar A, Subrahmanyam G, Mondal R et al (2021b) Nickel in terrestrial biota: comprehensive review on contamination, toxicity, tolerance and its remediation approaches. Chemosphere. https://doi.org/10.1016/j.chemo sphere.2021.129996

Kumar A, Kumar M, Pandey R, ZhiGuo Y, Cabral-Pinto M (2021c) Forest soil nutrient stocks along altitudinal range of Uttarakhand Himalayas: An aid to Nature Based Climate Solutions. CATENA 207:105667. https://doi.org/10.1016/j.catena.2021.105667

Lionard M, Muylaert K, Gansbeke DV, Vyverman W (2005) Influence of changes in salinity and light intensity on growth of phytoplankton communities from the Schelde river and estuary (Belgium/The Netherlands). Hydrobiologia 540:105-115

Matta G (2020) Science communication as a preventative tool in the COVID19 pandemic. Humanit Soc Sci Commun 2020(7):159. https://doi.org/10.1057/s41599-020-00645-1

Matta G, Kumar A (2017a) Health risk water hygiene, science and communication. Essence Int J Environ Conserv Rehab VIII 1:179-186

Matta G, Kumar A (2017b) Role of Science and Communication in health and hygiene: a case Study. Essence Int J Environ Conserv Rehab 8(2):95-101 
Matta G, Uniyal DP (2017) Assessment of species diversity and impact of pollution on limnological conditions of River Ganga. Int $\mathbf{J}$ Water 11(2):87-102. https://doi.org/10.1504/IJW.2017.083759

Matta G, Srivastava S, Pandey RR, Saini KK (2015a) Assessment of physicochemical characteristics of Ganga Canal water quality in Uttarakhand. Environ Dev Sustainability. https://doi.org/10.1007/ s10668-015-9735-x

Matta G, Kumar A, Kumar A, Naik PK, Kumar A (2018a) Applicability of heavy metal indexing on Ganga River System assessing heavy metals toxicity and ecological impact on river water quality. INAE Lett off J Indian Natl Acad Eng. https://doi.org/10.1007/ s41403-018-0041-4

Matta G, Kumar A, Tiwari AK, Naik PK, Berndtsson R (2018b) HPI appraisal of concentrations of heavy metals in Dynamic and static flow of Ganga River System. Environ Dev Sustain. https://doi.org/ 10.1007/s10668-018-01182-3

Matta G, Naik PK, Machell J, Kumar A, Gjyli L, Tiwari AK, Kumar A (2018c) Comparative study on seasonal variation in hydrochemical parameters of Ganga river water using comprehensive pollution index (CPI) at Rishikesh, (Uttarakhand) India. Desalin Water Treat 118:87-95. https://doi.org/10.5004/dwt.2018.22487

Matta G, Kumar A, Naik PK, Tiwari AK, Berndtsson R (2018d) Ecological analysis of nutrient dynamics and phytoplankton assemblage in the Ganga River System, Uttarakhand. Taiwan Water Conserv 66(1):1-12

Matta G, Nayak A, Kumar A, Kumar P (2020a) Water quality assessment using NSFWQI, OIP and multivariate techniques of Ganga River system, Uttarakhand, India. Appl Water Sci 10:206. https:// doi.org/10.1007/s13201-020-01288-y

Matta G, Nayak A, Kumar A, Kumar P (2020b) Evaluation of heavy metals contamination with calculating the pollution index for Ganga River System. Taiwan Water Conserv. https://doi.org/10. 6937/TWC.202009/PP_68(3).0005

Matta G, Nayak A, Kumar A, Kumar P (2020c) Determination of water quality of Ganga River System in Himalayan region, referencing indexing techniques. Arab J Geosci 13:1027. https://doi.org/10. 1007/s12517-020-05999-z

McCarthy MF (2004) Should we restrict chloride rather than sodium? Med Hypotheses 63(1):138-148

Mishra A (2010) Assessment of water quality using principal component analysis: a case study of the river Ganges. J Water Chem Technol 32:227-234. https://doi.org/10.3103/S1063455X100400 77

Mishra S, Kumar A, Shukla P (2015) Study of water quality in Hindon River using pollution index and environmetrics, India. Desalin Water Treat. https://doi.org/10.1080/19443994.2015.1098570

Ministry of Environment and Forest (MoEF) (2009) Status paper on River Ganga, State of Environment and Water Quality, National River Conservation Directorate Ministry of Environment and Forests, Government of India

National River Conservation Directorate (NRCD) (2009) Status paper on River Ganga: State of Environment and Water Quality. Ministry of Environment and Forests, New Delhi

Osei J, Nyame F, Armah T, Osae S, Dampare S, Fianko J, Adomako D, Bentil N (2010) Application of multivariate analysis for identification of pollution sources in the Densu Delta Wetland in the Vicinity of a Landfill Site in Ghana. J Water Resour Prot 2(12):1020-1029

Pathak H, Limaye SN (2011) Study of seasonal variation in groundwater quality of sagar city (India) by principal component analysis. J Chem 8:2000-2009

Poonam T, Tanushree B, Sukalyan C (2013) Water quality indicesimportant tools for water quality assessment: a review. Int $\mathrm{J}$ Adv Chem IJAC 1(1):15-28

Report on Water Sector for Uttarakhand (2018) http://nwm.gov.in/sites/ default/files/Report_Draft-SSAP_Uttarakhand.pdf
Sargaonkar A, Deshpande V (2003) Development of an overall index of pollution for surface water based on a general classification scheme in Indian context. Environ Monit Assess 89(1):43-67

Sharma M, Kansal A, Jain S (2015) Application of multivariate statistical techniques in determining the spatial temporal water quality variation of Ganga and Yamuna Rivers present in Uttarakhand State, India. Water Qual Expo Health 7:567-581. https://doi.org/ 10.1007/s12403-015-0173-7

Shukla AK, Ojha CSP, Garg RD (2017) Application of Overall Index of Pollution (OIP) for the assessment of the Surface Water Quality in the Upper Ganga River Basin, India. Development of Water Resources in India. Springer, Cham, Switzerland, pp 135-149

Simeonov VJ, Stratis CJ, Samara GJ, Zachariadis D, Voutsa A, Anthemidis M, Sofriniou T, Koumtzis T (2003) Assessment of the surface water quality in Northern Greece. Water Res 37(17):4119-4124

Simeonov V, Simeonova P, Tsitouridou R (2004) Chemometric quality assessment of surface waters: two case studies. Ecol Chem Eng 11:449-469

Singh KP, Malik AD, Mohan S, Sinha S (2004) Multivariate statistical techniques for the evaluation of spatial and temporal variations in water quality of Gomti River (India) - a case study. Water Res 38(18):3980-3992

Singh KP, Malik A, Sinha S (2005) Water quality assessment and apportionment of pollution sources of Gomti river (India) using multivariate statistical techniques: a case study. Anal Chim Acta 538:355-374

Singh P, Kumar A, Mishra S (2021) Performance evaluation of conservation plan for freshwater lakes in India through a scoring methodology. Environ Dev Sustain 23:3787-3810. https://doi.org/10. 1007/s10668-020-00744-8

Stoate C, Baldi A, Beja P, Boatman ND, Herzon I, Van DA, De Snoo GR, Rakosy L, Ramwell C (2009) Recent developments in life cycle assessment ecological impacts of early 21 st century agricultural change in Europe-a review. J Environ Manag 91(1):22-46

Tare V, Yadav ASV, Purnendu B (2003) Analysis of photosynthetic activity in the most polluted stretch of river Ganga. Water Res 37:67-77

Tiemeyer B, Kahle P, Lennartz B (2006) Nutrient losses from artificially drained catchments in North-Eastern Germany at different scales. Agric Water Manag 85(1):47-57

Trikoilidou E, Samiotis G, Trikritzis L (2017) Evaluation of water quality indices adequacy in characterizing the physico-chemical water quality of lakes. Environ Process 4(1):35-46

Tyagi S, Sharma B, Singh P, Dobhal R (2013a) Water quality assessment in terms of water quality index. Am J Water Resour 1(3):34-38

Tyagi VK, Bhatia A, Gaur RZ, Khan AA, Ali M, Khursheed A, Kazmi AA (2013b) Impairment in water quality of Ganges River and consequential health risks on account of mass ritualistic bathing. Desalin Water Treatment 51(10-12):2121-2129

United States Environmental Protection Agency (USEPA) (2000) Newport Bay Toxics TMDL Freshwater Flow and Seasonal Variation. Technical Support Document, Part B, 1-6

Vieira JS, Pires JCM, Martins FG, Vilar VJP, Boaventura RAR, Botelho CMS (2012) Surface water quality assessment of Lis River using multivariate statistical methods. Water Air Soil Pollution. https://doi.org/10.1007/s11270-012-1267-5

World Health Organization (WHO) (2011) Guidelines for drinkingwater quality, 4 th edn. World Health Organization, Geneva

WRI Aqueduct, WHO Global Health (2019) Observatory. Retrieved from World Resources Institute website: https://www.wri.org/ aqueduct.

Publisher's Note Springer Nature remains neutral with regard to jurisdictional claims in published maps and institutional affiliations. 